\title{
List of Maps and Illustrations
}

Fig. 1.0 World map by Nicola van Sype, 1581. Photo: Library of Congress, Geography and Map Division — 10

Fig. 1.1 Jerusalem civitas sancta, olim metropolis regni Judaici, hodie vero colonia Turcae. From the Cosmographia universalis by Sebastian Münster (1488-1552), first published $1554-12$

Fig. 1.2 Johan Rantzau (1492-1565). Engraving from Trap's collection, 1867. Photo: Assens Lokalarkiv, Denmark - 14

Fig. 1.3 View of Copenhagen, 1587. Photo: The Royal Danish Library (Det Kongelige Biblioteks billedsamling), Copenhagen -15

Fig. 1.4 Predella (1575-1600) of the altarpiece in Tinglev Church, Denmark. Photo: National Museum of Denmark (Nationalmuseet), Copenhagen, Arnold Mikkelsen 19

Fig. 1.5 Lucas Cranach the Younger, The Creation: Adam and Eve in Paradise. Woodcut from the second edition of Martin Luther's complete Bible, printed by Hans Lufft, Wittenberg, 1535. Photo: Bridwell Library, Elizabeth Perkins Prothro Bible Collection - 22

Fig. 1.6 Title page of Arent Berntsen, Danmarckis oc Norgis Fructbar Herlighed [The fruitful delights of Denmark and Norway], Copenhagen 1650-1655. Photo: National Library of Norway (Nasjonalbiblioteket), Oslo - 26

Fig. 1.7 Panel commemorating the rebuilding of Kvernes Church, Norway, 1633. Photo: Tone Marie Olstad, NIKU (Norwegian Institute for Cultural Heritage Reseach) - 39

Fig. 1.8 The Raising of Lazarus and the New Jerusalem. Detail of epitaph, c.1695, Ringkøbing Church, Denmark. Photo: National Museum of Denmark (Nationalmuseet), Copenhagen, Arnold Mikkelsen - 45

Fig. 2.1 Moses with the law tablets. Illustration to Decem praecepta Vuittenbergensi predicata populo per. P. Martinum Luther Augustinianum. (Leipzig: Valentin Schumann, 1518). Wren Library, Trinity College, Cambridge, Hare 38.183. Credits: Master and Fellows of Trinity College, Cambridge - $\mathbf{5 0}$

Fig. 3.1 Nicholas Poussin, The Destruction of the Temple at Jerusalem (1638), oil on canvas. Public domain. Vienna, Kunsthistorisches Museum, www.khm.at/de/object/78b9cab199/ - 54

Fig. 4.1 Title page of Anthonius Margaritha, Der gantz Jüdisch glaub (On the entire Jewish faith), Augsburg: H. Steiner, $1530-62$

Fig. 4.2 Ahasver. Title page from a Danish popular song from 1705: En sandferdig Bertetning om Jerusalems Skoemager, Haferus kaldet, som nu over sytten hundrede Aar haver vandret af et $i$ et andet Land, og efter Beretning skal være seet udi adskillige Provinzer udi Danmark og Norge, og med det første er forventendes til Smaa-Landene [A true account of the shoemaker of Jerusalem, called Haferus, who has wandered about in all lands for seventeen hundred years, and according to witnesses is seen in several provinces of Denmark and Norway, and is soon expected to Smaa-Landene (Eastern Norway)]. Photo: The Royal Danish Library (Det Kongelige Bibliotek), Copenhagen - 68

Fig. 5.0 Map of the Scandinavian countries. Septentrionaliv regionvm Svetiæ Gothiæ Norvegiæ Daniæ et terrarum adiacetium recens exactaque descriptio, Jode, G. de Algoet, Lievin, $1570-70$ 
Fig. 5.1 a. The imperial crown of the Holy Roman Empire of German Nation. b. Detail of the imperial crown. Photo: Kaiserliche Schatzkammer / Kunsthistorisches Museum, Wien -72

Fig. 5.2 Lucas Cranach the Elder, Portrait of Johannes Bugenhagen Pommeranus, 1537. Oil on wood. Photo: Wikimedia Commons - 82

Fig. 5.3 The coronation of King Frederik II (1534-88). The engraving shows the coronation procession to the Cathedral of Our Lady in Copenhagen. Photo: The Royal Danish Library (Det Kongelige Bibliotek), Copenhagen - 84

Fig. 5.4 Louis de Chomond-Boudan, The coronation of King Frederik II in the Cathedral of Our Lady, Copenhagen, 13 August 1559. Coloured engraving. Photo: The Royal Danish Library (Det Kongelige Bibliotek), Copenhagen - 89

Fig. 5.5 The seal of King Christian III. After Bache, Niels, Nordens Historie (1885). Photo: Wikimedia Commons - 91

Fig. 5.6 The "Gimsøy-daler," 1546. Oslo University Museum of Cultural History (Kulturhistorisk museum). Photo: CC BY-SA 4.0; Lill-Ann Chepstow-Lusty. Oslo University Museum of Cultural History (Kulturhistorisk Museum) - 92

Fig. 6.1 Portrait of Christian III (1503-59), King of Denmark and Norway, Duke of Holstein and Schleswig. Photo: Wikimedia Commons - 98

Fig. 6.2 Georg Braun, Frans Hogenberg, and Simon Nouellanus, Hafnia Kopenhagen. 1587. Engraving. From Civitates orbis terrarum (1576-1600), vol. 4. Photo: The Royal Danish Library (Det Kongelige Bibliotek), Copenhagen - 101

Fig. 6.3 Portrait of Christian III. Tapestry from Kronborg Castle, 1581-1584. National Museum of Denmark. Photo: CC BY-SA, National Museum of Denmark (Nationalmuseet), Copenhagen -114

Fig. 6.4 Portrait of the deceased King Christian III. Copy of an original painting ascribed to Jost Verheiden. Malmø Kunstmuseum, Sweden. Photo: Wikimedia Commons - 116

Fig. 7.1 Copperplate engraving by Vallentin Staffanson Trautman in Biblia thet är: All then helgha Scrifft / På Swensko, Stockholm, 1618. Photo: National Library of Sweden (Kungliga biblioteket), Stockholm $-\mathbf{1 2 0}$

Fig. 7.2 Copperplate engraving by Jan van de Velde in BIBLIA, Thet är: All then Helga Skrifft, PÅ SWENSKO, Stockholm, 1655. Photo: National Library of Sweden (Kungliga biblioteket), Stockholm $-\mathbf{1 3 0}$

Fig. 8.1 King Gustav Vasa of Sweden with a ceremonial sword, painted in a law codex at the National Library of Sweden. Reproduction: Hans Lindahl — 148

Fig. 8.2 Engraving reproducing the incised decoration on Gustav Vasa's ceremonial royal sword (rikssvärd) of 1541. Collections of Kungl. Skattkammaren, The Royal Palace, Stockholm -160

Fig. 8.3 Engraving reproducing the incised decoration on Gustav Vasa's ceremonial royal sword (rikssvärd) of 1541. Collections of Kungl. Skattkammaren, The Royal Palace, Stockholm -160

Fig. 9.0 Model of the aedicula surrounding the Holy Sepulchre, brought from The Holy Land to Denmark in 1674. Photo: National Museum (Nationalmuseet), Copenhagen - 168

Fig. 9.1 View of Wittenberg seen from the South, 1556. Coloured woodcut. Workshop of Cranach -170 
Fig. 10.1 Heinrich Bünting, Heele Jordenes Kretz affmålningh / liik ett Klöffuer bladh ("The Entire Circle of the Earth depicted / like a clover leaf") (1595). Photo: The National Library of Norway (Nasjonalbiblioteket), Oslo - 182

Fig. 10.2 Sebastian Münster, Terra Sancta (1542). Photo: Barry Lawrence Ruderman Antique Maps Inc - 185

Fig. 10.3 Gerard Mercator, Amplissima Terrae Sanctae (1537). Photo: Bibliothèque nationale de France, Paris - 186

Fig. 10.4 Gerard Mercator, World Map (1538), re-engraved by Antonio Salamanca, c.1550. National Library of Norway (Nasjonalbiblioteket), Oslo - 188

Fig. 10.5 Abraham Ortelius: Abrahami Patriarchae Peregrinatio, from Parergon (1586). Photo: The David Rumsey Map Collection — 190

Fig. 10.6 Turcicum Imperium, Mercator/Hondius (1632) - 193

Fig. 10.7 Terra Sancta, Mercator/Hondius (1632) - 193

Fig. 10.8 Joannes Blaeu, Terra Sancta, from Atlas Maior (Amsterdam: Blaeu, 1662). Photo: Barry Lawrence Ruderman Antique Maps Inc - 194

Fig. 11.1 T-0 map drawn by Christiern Pedersen in 1521. Copy dated around 1550. From ms. Thott $7972^{\circ}$, fol. 277. Photo: The Royal Danish Library (Det Kongelige Bibliotek), Copenhagen - 198

Fig. 11.2 Detail from the Ringsaker tabernacle, produced in Antwerp in the 1530s, depicting the martyrdom of Saint Sebastian. Photo: Jan Haug, Hedmarksmuseets fotoarkiv, Hamar, Norway -220

Fig. 11.3 The body of Prince Svend is discovered and his famous sword recovered. Painting by Karel van Mander III (1609-70), commissioned by Christian IV before 1642. Photo: National Gallery of Denmark (Statens Museum for Kunst), Copenhagen - 222

Fig. 11.4 Christian IV's Order of the Armed Arm. Photo: De Danske Kongers Kronologiske Samling, Rosenborg Slot, Copenhagen - 223

Fig. 11.5 Medal struck by Christian IV. Reproduced from Schlegel 1771: facing p. 396. Photo: The Royal Danish Library (Det Kongelige Bibliotek), Copenhagen — 224

Fig. 11.6 Christian IV's collar of the Order of the Elephant depicting the Armed Arm. Photo: De Danske Kongers Kronologiske Samling, Rosenborg Slot, Copenhagen - 225

Fig. 11.7 Model of the Holy Sepulchre, brought from The Holy Land to Denmark in 1674. Photo: National Museum (Nationalmuseet), Copenhagen — 228

Fig. 11.8 Casket with relics from the Holy Land, brought to Denmark in 1674. Photo: National Museum (Nationalmuseet), Copenhagen - 229

Fig. 12.0 Fire of Copenhagen 1728. Hand-coloured woodcut of unknown provenience. Photo: Wikimedia Commons - 232

Fig. 12.1 Title page of Peder Tideman, Jerusalems oc Jødernis Jemmerlige oc Yncelige forstøringe/kaartelige aff Josephi Historie fordansket [The pitiful and miserable destruction of Jerusalem and the Jews briefly recorded in Danish after Joswphus' Historia] (1587). Image produced by ProQuest as part of Early European Books. www.proquest.com. Image published with permission of ProQuest and The Royal Danish Library, Copenhagen. Further reproduction is prohibited without permission -236

Fig. 12.2 From Christiern Pedersen, Alle Epistler och Evangelia som lesiss alle Søndage om aared [. . . ] (Jærtegnpostillen) (1515), fol. clxi. Image produced by ProQuest as part of Early European Books. www.proquest.com. Image published with 
permission of ProQuest and The Royal Danish Library, Copenhagen. Further reproduction is prohibited without permission $-\mathbf{2 4 2}$

Fig. 12.3 From Hans Tausen, Sommerdelen aff Postillen berid aff M. Hans Taussen/ Predickere $\ddot{y}$ Kiøbenhaffn (1539), fol. CXCIlv. Image produced by ProQuest as part of Early European Books. www.proquest.com. Image published with permission of ProQuest and The Royal Danish Library, Copenhagen. Further reproduction is prohibited without permission -246

Fig. 13.1 Isaac van Geelkerck, city plan of Christiania, 1648. Photo: National Library of Norway (Nasjonalbiblioteket), Oslo - 258

Fig. 13.2 Francois Roger de Gaignieres, Veue de la Ville de Christiania, 1685. Photo: Oslo Museum -265

Fig. 14.1 Epitaph of Christen Staffensen Bang and his wife Helene Hansdatter, Romedal Church, 1636. Photo: Anno museum, Domkirkeodden, Hamar - 266

Fig. 14.2 Isaac van Geelkerck, From the acclamation of King Frederik III at Akershus Castle, Christiania, 1648. Photo: The Royal Danish Library (Det Kongelige Biblioteks billedsamling), Copenhagen -270

Fig. 15.1 Anonymous propaganda painting from the late sixteenth century. Photo: Karl Ragnar Gjertsen, Aust-Agder museum og arkiv-KUBEN, Arendal - 282

Fig. 16.1 Title page from Nårgra wijsor om Anthichristum [Some Songs about the Antichrist] (1536). Photo: National Library of Sweden (Kungliga biblioteket), Stockholm 298

Fig. 16.2 Nårgra wijsor om Anthichristum, with the Lord's Prayer in Swedish (O fadher wår i himmelrick) (unpaginated pages 4-6). Photo: National Library of Sweden (Kungliga biblioteket), Stockholm - $\mathbf{3 1 0}$

Fig. 17.0 Epitaph, c.1603, from Kerteminde Church, Funen. Photo: National Museum of Denmark (Nationalmuseet), Copenhagen, Arnold Mikkelsen - 314

Fig. 17.1 Epitaph, 1647, from Vilstrup Church in southern Jutland. Photo: National Museum of Denmark (Nationalmuseet), Copenhagen, Arnold Mikkelsen - $\mathbf{3 1 6}$

Fig. 17.2 Epitaph of the Godtzen family, 1662, Stavanger Cathedral, Western Norway. Photo: Inge Bruland - 322

Fig. 17.3 The celestial architecture, painted in all four vault chambers of Vokslev Church in northern Jutland c.1720-30. Photo: Martin Wangsgaard Jürgensen — 323

Fig. 17.4 Emblem on pew end in the old monastery church at Horsens in Jutland, painted 1738. Photo: National Museum of Denmark (Nationalmuseet), Copenhagen, Niels Elswing - 326

Fig. 17.5 The waters of salvation flow like a road or passage to Jerusalem and out this world. Etching by unknown artist. Dating from the first half of the seventeenth century. Photo: Herzog August Bibliothek, Wolfenbüttel - 327

Fig. 17.6 The Baroque altarpiece in Undløse Church on the island of Zealand, dating from 1644. Photo: Martin Wangsgaard Jürgensen -329

Fig. 17.7 Praising the Lord. An illustration from the Book of Revelation. Etching by Simon Thaddäus Sondermayr, c.1730-50. Photo: Herzog August Bibliothek, Wolfenbüttel - 331

Fig. 17.8 The interior of Engum Church in eastern Jutland looking east. Photo: National Museum of Denmark (Nationalmuseet), Copenhagen, Arnold Mikkelsen - 337

Fig. 17.9 The ornate chancel arch grille with cherubs in Hansted Church, eastern Jutland, dating from 1722. Photo: Carsten Bach-Nielsen — 338 
Fig. 17.10 Christ leading the redeemed into Heaven - The New Jerusalem. Painting by Joakim Skovgaard in Viborg Cathedral, painted 1899-1907. Photo: National Museum of Denmark (Nationalmuseet), Copenhagen - 341

Fig. 17.11 Christ resurrected. Altarpiece in Gerskov Church on Funen, painted 1927 by Ellen Hofman-Bang. National Museum of Denmark (Nationalmuseet), Copenhagen, Arnold Mikkelsen - $\mathbf{3 4 2}$

Fig. 17.12 The resurrected Christ. Limestone altarpiece in Revninge Church on Funen, carved 1952 by Gunnar Hansen. Photo: National Museum of Denmark (Nationalmuseet), Copenhagen, Arnold Mikkelsen - 343

Fig. 18.1 The city plan of Trondheim 1681, the small version (59 x $45 \mathrm{~cm}$ ). Photo: Regional State Archives in Trondheim - 344

Fig. 18.2 Jean Gaspard de Cicignon. Copper engraving from 1674 by Willem van der Laegh (310x209 mm). Photo: National Gallery of Denmark (Statens Museum for Kunst), Copenhagen $\mathbf{3 4 8}$

Fig. 18.3 City plan of Kristiansand. Map from 1764. The Norwegian Mapping Authority (Kartverket) 354

Fig. 18.4 Athanasius Kircher. Copper engraving by Cornelis Bloemaert 1665 (155x100 mm). Germanisches Nationalmuseum, Nuremberg - 356

Fig. 18.5 The city plan of Trondheim 1681, the large version - drawn copy from 1881. Municipal Archives in Trondheim — 357

Fig. 18.6 The street Munkegaten seen from the tower of the cathedral. The island of Munkholmen as a vanishing point at the other end. Photo: Andreas Solberg - 363

Fig. 18.7 Melancholia I. Copper engraving $(24 \times 18.5 \mathrm{~cm})$ from 1513-14 by Albrecht Dürer. Photo: The Metropolitan Museum of Art, New York. The Square of Jupiter can be seen in the wall 366

Fig. 19.1 King Christian V of Denmark-Norway receives his royal crown from the hand of God. Engraving, late seventeenth-century. Photo: The Royal Danish Library (Det Kongelige Biblioteks billedsamling), Copenhagen - 368

Fig. 19.2 Woodcut from Willich Westhov, Emblemata, 1640, fol. 9. Photo: The Royal Danish Library (Det Kongelige Bibliotek), Copenhagen — 376

Fig. 19.3 Woodcut from Willich Westhov, Emblemata, 1640, fol. 7. Photo: The Royal Danish Library (Det Kongelige Bibliotek), Copenhagen - 376

Fig. 19.4 Reconstruction of Jerusalem and the Temple seen from the Mount of Olives, from Jan van der Avelen's Atlas Major, 1687, Bd. 60, tvl. Photo: The Royal Danish Library (Det Kongelige Bibliotek), Copenhagen - 382

Fig. 20.1 Portrait of Michael Praetorius (1571-1621)., General preface to Musae Sioniae (actually in Musae Sioniae I), The Royal Danish Library (Det Kongelige Bibliotek), Copenhagen, Box A 19.3000, mu 6602.2132-35, U260. CCO-Licence - 390

Fig. 20.2 Book cover, Cantus part from the Motectae et Psalmi latini and Musae Sioniae $I-I V$, The Royal Danish Library (Det Kongelige Bibliotek), Copenhagen, Box A 19.3000, mu 6602.2131, U260. CCO-Licence - 400

Fig. 20.3 Handwritten dedication to King Christian IV by Praetorius, Cantus part from the Motectae et Psalmi latini and Musae Sioniae I-IV, The Royal Danish Library (Det Kongelige Bibliotek), Copenhagen, Box A 19.3000, mu 6602.2131, U260. CCOLicence $-\mathbf{4 0 2}$

Fig. 20.4 Handwritten note by Praetorius (front side), Copy from Peter Peterson Botzen (1707), The Danish National Archives, Copenhagen, Rentekammeret $2214.58-403$ 
Fig. 20.5 Handwritten note by Praetorius (rear side), The Danish National Archives, Copenhagen, Rentekammeret $2214.58-403$

Fig. 20.6 Motectae et Psalmi latini, title woodcut, The Royal Danish Library (Det Kongelige Bibliotek), Copenhagen, Box A 19.3000, mu 6602.213235, U260. CCO-Licence - 411

Fig. 20.7 Polyhymnia Caduceatrix \& Panegyrica, title woodcut, The Royal Danish Library (Det Kongelige Bibliotek), Copenhagen, Box A 6.4000, mu 6602.2631, U260. CCO-Licence - 412

Fig. $21.1 \quad$ N. Goldmann, Elementa architecturae, Leiden 1658. p. 22. Ms Thott $2672^{\circ}$. Photo: The Royal Danish Library (Det Kongelige Bibliotek), Copenhagen $-\mathbf{4 1 6}$

Fig. 21.2a-2b The Jerusalem Church in Trankebar, Copper engraving on a card, Germany 1700-1750. Photo: The Royal Danish Library (Det Kongelige Bibliotek), Copenhagen. 434

Fig. 21.3 Engraving by I. lacob Kleinschmidt, ca. 1730. The Evangelical Church in East-India. Photo: The Royal Danish Library (Det Kongelige Biblioteks billedsamling), Copenhagen - 436

Fig. 21.4 The New Jerusalem Church, Tranquebar, India. Photo: National Museum of Denmark (Nationalmuseet), Copenhagen, Nils Finn Munch-Petersen — 438

Fig. 22.1 Johan Valentin Andreae, Reipublicae Christianopolitanae description, woodcut 1619. Photo: Wikimedia Commons — 440 